\title{
Highly-Efficient Orange-Red/Red Excimer Fluorescence from Dimeric $\pi-\pi$ Stacking of Perylene and Its Nanoparticle Applications
}

\author{
Yue Shen, ${ }^{+,{ }^{\perp}}$ Zhe Zhang, ${ }^{+, \perp}$ Haichao Liu, ${ }^{+,{ }^{\perp}}$ Yan Yan, ${ }^{\ddagger}$ Shitong Zhang ${ }^{\dagger}$, Bing Yang ${ }^{*,+}$ and Yuguang $\mathrm{Ma}^{\S}$ \\ ${ }^{+}$State Key Laboratory of Supramolecular Structure and Materials, College of Chemistry, Jilin University, Changchun, 130012, Peo- \\ ple's Republic of China \\ ‡ State Key Laboratory of Inorganic Synthesis and Preparative Chemistry, College of Chemistry, Jilin University, Changchun, 130012, \\ People's Republic of China \\ ${ }^{\S}$ State Key Laboratory of Luminescent Materials and Devices, Institute of Polymer Optoelectronic Materials and Devices, South \\ China University of Technology, Guangzhou, 510640, People's Republic of China
}

\section{Contents}

\section{S-I Characterization and Measurements}

\section{S-II Synthesis and Preparation}

S-III Figures and Tables

S-IV References 


\section{S-I Characterization and Measurements}

General Details: ${ }^{1} \mathrm{H}$ NMR spectra and ${ }^{13} \mathrm{C}$ NMR spectra were recorded on a Bruker AVANCE 500 spectrometer, using tetramethylsilane (TMS; $\delta=0 \mathrm{ppm}$ ) as the internal standard. The MALDI-TOF-MS mass spectra were recorded using an AXIMA-CFRTM plus instrument. Fluorescence images were acquired on an inverted fluorescence microscope (Olympus IX71, Japan) with a 20x (0.45 NA LUCPLFLN) objective. The excitation light was generated from a mercury lamp, filtered by a 445/45-nm band-pass filter. The fluorescent signal was filtered by a 593-nm long-pass filter and imaged on an Andor iXon3 frame transfer EMCCD (Andor, UK).

The average lifetime was calculated according to the equation:

$<\tau>=\left(\mathrm{A}_{1} \tau_{1}^{2}+\mathrm{A}_{2} \tau_{2}^{2}\right) /\left(\mathrm{A}_{1} \tau_{1}+\mathrm{A}_{2} \tau_{2}\right)$.

\section{S-II Synthesis and Preparation}<smiles>Brc1cccc(N(c2ccccc2)c2ccccc2)c1</smiles>

mTPA-Br
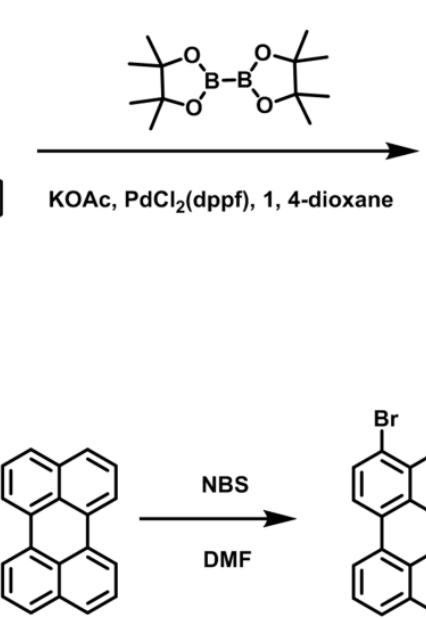

PE<smiles>CC1(C)OB(c2cccc(N(c3ccccc3)c3ccccc3)c2)OC1(C)C</smiles>

mTPA-B

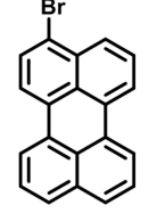

3Br-PE
$\mathrm{Pd}\left(\mathrm{PPh}_{3}\right)_{4}, \mathrm{~K}_{2} \mathrm{CO}_{3}, \mathrm{~N}_{2}$

Toluene, Water, Ethanol $\int$

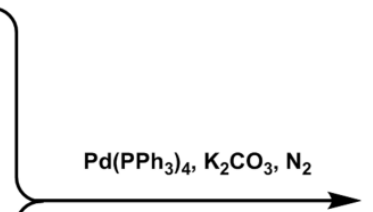

Toluene, Water, Ethanol

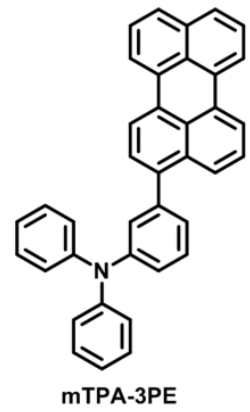<smiles></smiles>

KOAc, $\mathrm{PdCl}_{2}$ (dppf), 1, 4-dioxane<smiles>CC1(C)OB(c2ccc3c(c2)C2(c4ccccc4-c4ccccc42)c2ccccc2-3)OC1(C)C</smiles>

2SF-B

Scheme S1. Synthetic routes to mTPA-3PE and 2SF-3PE. 
Synthesis of 3-bromoperylene (3Br-PE): Compound 3Br-PE was prepared according to previous reports. ${ }^{1}$

\section{Synthesis of $N, N$-diphenyl-3-(4,4,5,5-tetramethyl-1,3,2-dioxaborolan-2-yl)aniline (mTPA-B): A} mixture of 3-bromo-N, N-diphenylaniline (mTPA-Br) (973 mg, $3.0 \mathrm{mmol}$ ), bis(pinacolato)diboron (1.02 g, $4 \mathrm{mmol}), \mathrm{PdCl}_{2}$ (dppf) (51 mg, $\left.0.06 \mathrm{mmol}\right), \mathrm{KOAc}(1.47 \mathrm{~g}, 15.0 \mathrm{mmol})$ and $35 \mathrm{~mL}$ 1, 4-dioxane was degassed and recharged with nitrogen. After stirred and refluxed at $85{ }^{\circ} \mathrm{C}$ for $48 \mathrm{~h}$ under nitrogen atmosphere, the mixture was washed with distilled water and then extracted with dichloromethane. The organic phase was dried with anhydrous sodium sulfate, filtered and concentrated in vacuum. The crude product was purified by passing it through a column of silica gel using petroleum ether/dichloromethane (4:1) as mobile phase. The desired compound was obtained as white powder with an $88 \%$ yield (980 mg). ${ }^{1} \mathrm{H}$ NMR (500 MHz, DMSO-d6, $\left.\delta\right): ~ 7.36(\mathrm{~d}, J=6.9,1 \mathrm{H}), 7.32(\mathrm{~d}, J=2.8,2 \mathrm{H}), 7.30(\mathrm{~d}, J=7.4,4 \mathrm{H}), 7.14$ $(\mathrm{d}, J=7.7,1 \mathrm{H}), 7.04(\mathrm{t}, J=7.4,2 \mathrm{H}), 6.98(\mathrm{~d}, J=7.6,4 \mathrm{H}), 1.26(\mathrm{~s}, 12 \mathrm{H})$. MALDI-TOF MS (mass m/z): $371.08\left[\mathrm{M}^{+}\right]$

Synthesis of 3-(perylen-3-yl)-N, $N$-diphenylaniline (mTPA-3PE): A mixture of mTPA-B (410 mg, 1.1 mmol), 3Br-PE (331 mg, $1.0 \mathrm{mmol}), \mathrm{K}_{2} \mathrm{CO}_{3}(3.31 \mathrm{~g}, 24 \mathrm{mmol}), 12 \mathrm{~mL}$ distilled water, $18 \mathrm{~mL}$ toluene and $9 \mathrm{~mL}$ anhydrous ethanol was degassed and recharged with nitrogen. Then $\mathrm{Pd}\left(\mathrm{PPh}_{3}\right)_{4}(23 \mathrm{mg}, 0.02 \mathrm{mmol})$ was added in the mixture as catalyst, and the mixture was degassed and recharged with nitrogen again. After stirred and refluxed at $90{ }^{\circ} \mathrm{C}$ for $24 \mathrm{~h}$ under nitrogen atmosphere, the mixture was extracted with dichloromethane. The organic phase was concentrated in vacuum. The crude product was purified by passing it through a column of silica gel using petroleum ether as mobile phase. The desired compound was obtained as orange powder with a $60 \%$ yield $(294 \mathrm{mg})$. The product was further purified by sublimation. ${ }^{1} \mathrm{H}$ NMR $\left(500 \mathrm{MHz}, \mathrm{DMSO}-d_{6}, \delta\right): 8.40(\mathrm{~m}, 4 \mathrm{H}), 7.81(\mathrm{~d}, J=8.1 \mathrm{~Hz}, 2 \mathrm{H}), 7.70(\mathrm{~d}, J=8.0$ $\mathrm{Hz}, 1 \mathrm{H}), 7.58-7.50(\mathrm{~m}, 3 \mathrm{H}), 7.50-7.44(\mathrm{~m}, 2 \mathrm{H}), 7.35(\mathrm{t}, J=7.9 \mathrm{~Hz}, 4 \mathrm{H}), 7.18(\mathrm{~d}, J=7.3 \mathrm{~Hz}, 1 \mathrm{H}), 7.14$ $(\mathrm{d}, J=8.4 \mathrm{~Hz}, 4 \mathrm{H}), 7.07(\mathrm{~m}, 3 \mathrm{H}), 7.03(\mathrm{~s}, 1 \mathrm{H}) .{ }^{13} \mathrm{C} \mathrm{NMR}\left(125 \mathrm{MHz}, \mathrm{CDCl}_{3}, \delta\right): 147.96,147.78,141.73$ $139.62,134.70,132.79,131.40,131.24,130.67,129.29,128.65,127.79,127.59,126.63,126.46,126.05$ 
125.44, 124.38, 124.16, 122.91, 122.71, 120.35, 120.12, 119.90. MALDI-TOF MS (mass m/z): 496.7

$\left[\mathrm{M}^{+}\right]$

\section{Synthesis of 2-(9,9'-spirobi[fluoren]-2-yl)-4,4,5,5-tetramethyl-1,3,2-dioxaborolane (2SF-B): A} mixture of 2-bromo-9,9'-spirobi[fluorene] (2SF-Br) (1.186 g, $3.0 \mathrm{mmol})$, bis(pinacolato)diboron (1.270 g, $5 \mathrm{mmol}), \mathrm{PdCl}_{2}(\mathrm{dppf})(51 \mathrm{mg}, 0.06 \mathrm{mmol}), \mathrm{KOAc}(1.47 \mathrm{~g}, 15.0 \mathrm{mmol})$ and $35 \mathrm{~mL} \mathrm{1,} \mathrm{4-dioxane} \mathrm{was}$ degassed and recharged with nitrogen. After stirred and refluxed at $85{ }^{\circ} \mathrm{C}$ for $48 \mathrm{~h}$ under nitrogen atmosphere, the mixture was washed with distilled water and then extracted with dichloromethane. The organic phase was dried with anhydrous sodium sulfate, filtered and concentrated in vacuum. The crude product was purified by passing it through a column of silica gel using petroleum ether/dichloromethane (4:1) as mobile phase. The desired compound was obtained as white powder with a $75 \%$ yield (990 mg). ${ }^{1} \mathrm{H}$ NMR (500 MHz, DMSO-d6, $\left.\delta\right): 8.06(\mathrm{~m}, 4 \mathrm{H}), 7.73$ (d, J= 7.6 Hz, 1H), $7.44(\mathrm{~m}, 3 \mathrm{H}), 7.17(\mathrm{~m}, 3 \mathrm{H})$, $6.84(\mathrm{~s}, 1 \mathrm{H}), 6.65(\mathrm{~d}, J=7.7 \mathrm{~Hz}, 1 \mathrm{H}), 6.61(\mathrm{~d}, J=7.6 \mathrm{~Hz}, 2 \mathrm{H}), 1.19(\mathrm{~s}, 12 \mathrm{H})$. MALDI-TOF MS (mass $\mathrm{m} / \mathrm{z}): 442.05\left[\mathrm{M}^{+}\right]$.

Synthesis of 2-(perylen-3-yl)-9,9'-spirobi[fluorene] (2SF-3PE): A mixture of 2SF-B (486 mg, 1.1 mmol), 3Br-PE (331 mg, $1.0 \mathrm{mmol}), \mathrm{K}_{2} \mathrm{CO}_{3}(3.31 \mathrm{~g}, 24 \mathrm{mmol}), 12 \mathrm{~mL}$ distilled water, $18 \mathrm{~mL}$ toluene and $9 \mathrm{~mL}$ anhydrous ethanol was degassed and recharged with nitrogen. Then $\mathrm{Pd}\left(\mathrm{PPh}_{3}\right)_{4}(23 \mathrm{mg}, 0.02 \mathrm{mmol})$ was added in the mixture as catalyst, and the mixture was degassed and recharged with nitrogen again. After stirred and refluxed at $90{ }^{\circ} \mathrm{C}$ for $24 \mathrm{~h}$ under nitrogen atmosphere, the mixture was extracted with dichloromethane. The organic phase was concentrated in vacuum. The crude product was purified by passing it through a column of silica gel using petroleum ether as mobile phase. The desired compound was obtained as orange powder with a $47 \%$ yield $(267 \mathrm{mg})$. The product was further purified by sublimation. ${ }^{1} \mathrm{H}$ NMR $\left(500 \mathrm{MHz}, \mathrm{DMSO}-d_{6}, \delta\right): 8.37-8.29(\mathrm{~m}, 4 \mathrm{H}), 8.22(\mathrm{~d}, J=7.7 \mathrm{~Hz}, 1 \mathrm{H}), 8.13(\mathrm{~d}, J$ $=7.5 \mathrm{~Hz}, 1 \mathrm{H}), 8.01(\mathrm{~d}, J=7.7 \mathrm{~Hz}, 2 \mathrm{H}), 7.79(\mathrm{~d}, J=7.6 \mathrm{~Hz}, 2 \mathrm{H}), 7.60(\mathrm{dd}, J=8.0,1.5 \mathrm{~Hz}, 1 \mathrm{H}), 7.54$ (td, $J=7.8,2.6 \mathrm{~Hz}, 2 \mathrm{H}), 7.48(\mathrm{t}, J=7.9 \mathrm{~Hz}, 2 \mathrm{H}), 7.42(\mathrm{t}, J=7.5 \mathrm{~Hz}, 2 \mathrm{H}), 7.36(\mathrm{t}, J=8.2 \mathrm{~Hz}, 1 \mathrm{H}), 7.29(\mathrm{~d}, J$ $=7.8 \mathrm{~Hz}, 1 \mathrm{H}), 7.20(\mathrm{t}, J=7.1 \mathrm{~Hz}, 3 \mathrm{H}), 6.77(\mathrm{~d}, J=7.5 \mathrm{~Hz}, 2 \mathrm{H}), 6.69(\mathrm{~d}, J=7.5 \mathrm{~Hz}, 1 \mathrm{H}), 6.64(\mathrm{~s}, 1 \mathrm{H})$.

${ }^{13} \mathrm{C} \mathrm{NMR}\left(125 \mathrm{MHz}, \mathrm{CDCl}_{3}, \delta\right): 149.27,149.14,148.68,141.82,141.51,141.03,140.29,139.74,134.66$, 
$132.78,131.40,131.28,131.22,130.50,129.67,129.00,128.61,127.93,127.84,127.77,127.74,127.68$,

$126.58,126.38,125.94,125.63,124.14,124.08,120.28,120.24,120.09,120.06,119.77,66.07$. MALDI-

TOF MS (mass $m / z): 566.8\left[\mathrm{M}^{+}\right]$.

Preparation of nanoparticles: The nanoparticles were prepared using a reprecipitation method. The THF solution of PSMA and mTPA-3PE $(\mathrm{c}=1000 \mathrm{ppm})$ were prepared. Then $90 \mu \mathrm{L}$ PSMA solution was added to $10 \mu \mathrm{L}$ mTPA-3PE solution, after that extra $1.9 \mathrm{~mL}$ THF solvent was added to obtain a $2 \mathrm{~mL}$ mixture. The mixture was quickly injected into water $(10 \mathrm{~mL})$ under sonication to prepare the $10 \%$ nanoparticles. The other ratios (wt \%) were prepared following the same procedure. The prepared particles were evaporated by $\mathrm{N}_{2}$ flow at $70{ }^{\circ} \mathrm{C}$ to remove THF and the solution was concentrated, followed by filtration through a $0.2-\mu \mathrm{m}$ filter. Besides, the $2 \mathrm{SF}-3 \mathrm{PE}$ nanoparticles were prepared by the same way. Notable, the ratio of $80 \%$ was chose to use for cell imaging. The sample was diluted in Milli-Q water to $\mathrm{c}=30 \mathrm{ppm}$, then was incubated with Hela cell for $24 \mathrm{~h}$.

\section{S-III Figures and Tables}

Photophysical property of $\mathrm{MTPA}-3 \mathrm{PE}$
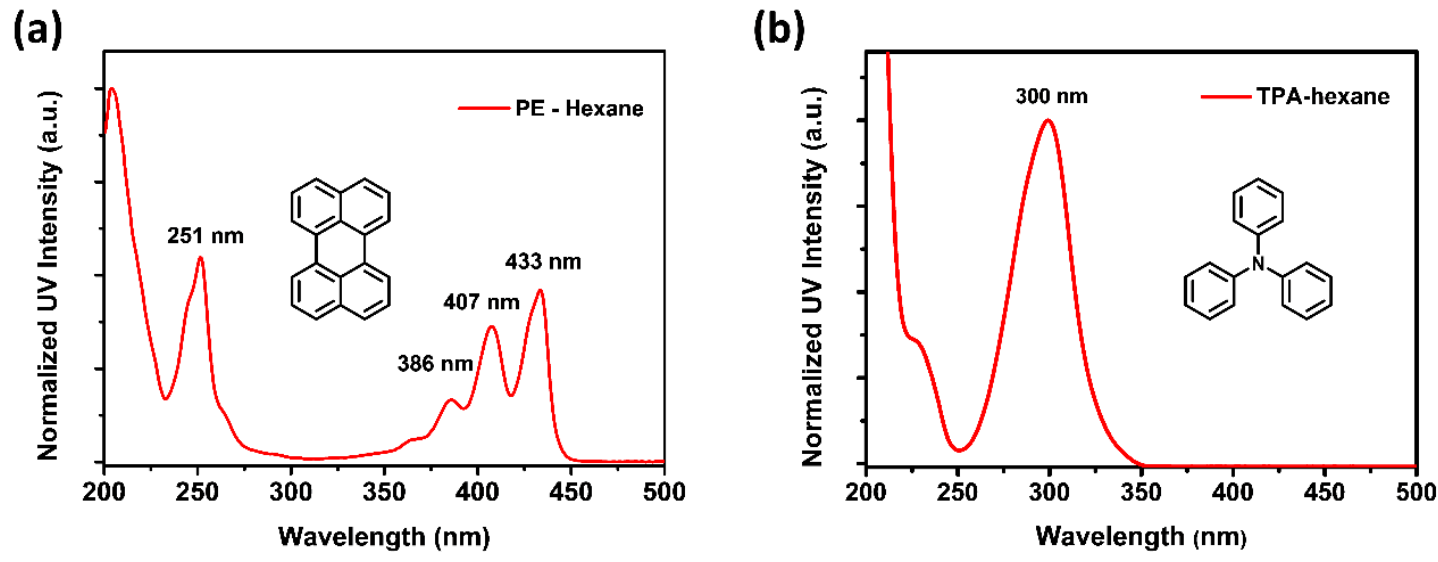

Figure S1. The UV-vis absorption (abs) spectra of (a) perylene (PE) and (b) triphenylamine (TPA) at concentration of $\sim 10^{-5} \mathrm{M}$ in hexane solution at room temperature. 
(a)

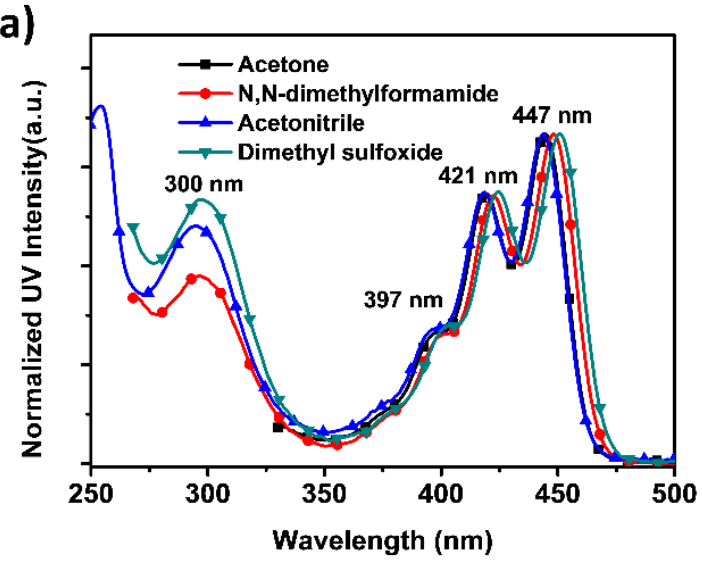

(b)

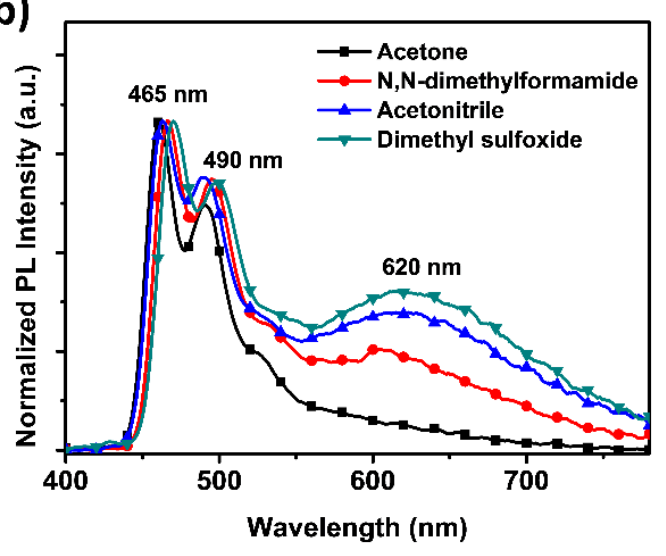

Figure S2. The (a) UV-vis absorption and (b) fluorescence spectra of mTPA-3PE in high polar solvents.

(a)

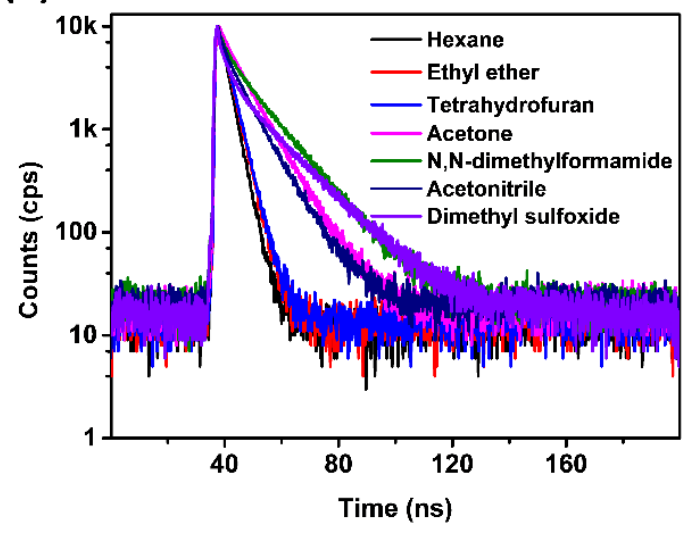

(b)

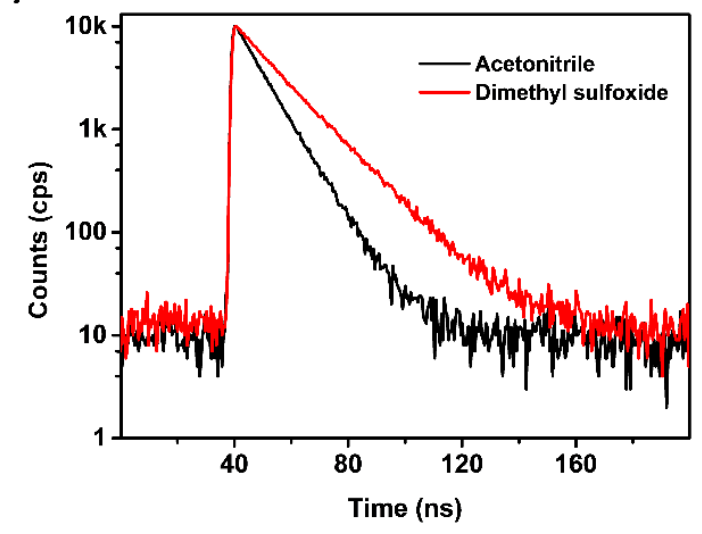

Figure S3. The lifetimes of mTPA-3PE solutions at concentration of $\sim 10^{-5} \mathrm{M}$ in different solvents. (a) These were recorded at $465 \mathrm{~nm}$, hexane $(\tau=3.21 \mathrm{~ns})$, ethyl ether $(\tau=3.66 \mathrm{~ns})$, tetrahydrofuran $(\tau=3.73$ $\mathrm{ns}$ ), acetone $(\tau=8.41 \mathrm{~ns}), \mathrm{N}, \mathrm{N}$-dimethylformamide $(\tau=8.41 \mathrm{~ns})$, acetonitrile $(\tau=8.16 \mathrm{~ns})$, dimethyl sulfoxide $(\tau=2.33 \mathrm{~ns}(19.68 \%), 14.68 \mathrm{~ns}(80.32 \%))$. (b) These were recorded at $620 \mathrm{~nm}$, acetonitrile $(\tau$ $=9.17 \mathrm{~ns})$, dimethyl sulfoxide $(\tau=14.82 \mathrm{~ns})$. 
(a)

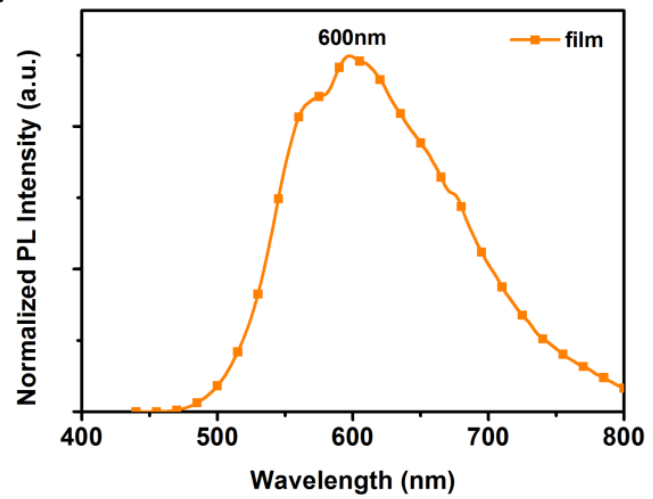

(b)

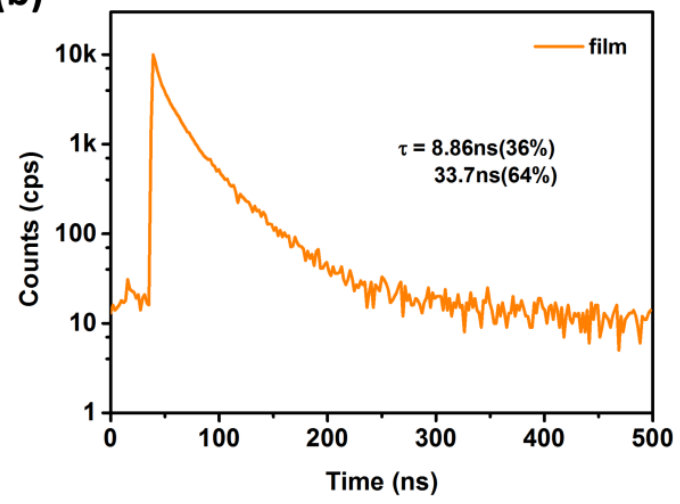

Figure S4. (a) Fluorescence spectrum and (b) lifetime of mTPA-3PE film. The thickness of neat film is about $50 \mathrm{~nm}$. The photoluminescence (PL) spectrum was excitated at $425 \mathrm{~nm}$, and lifetime was recorded at $600 \mathrm{~nm}$.

\section{Photophysical property of $2 S F-3 P E$}

(a)

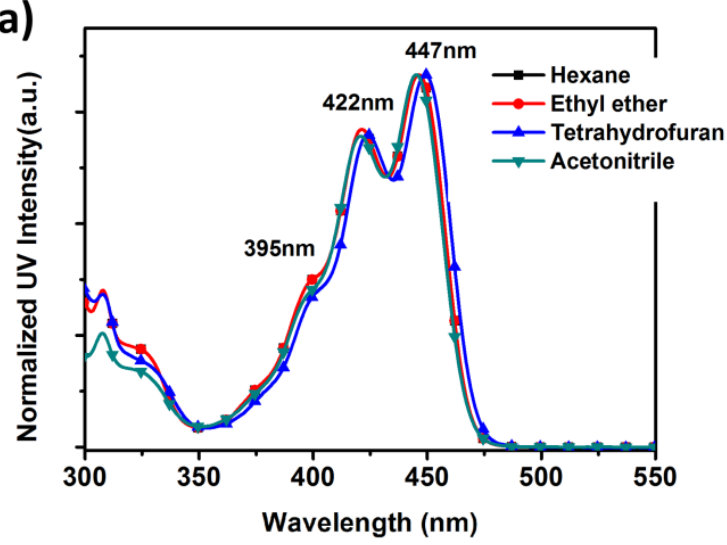

(b)

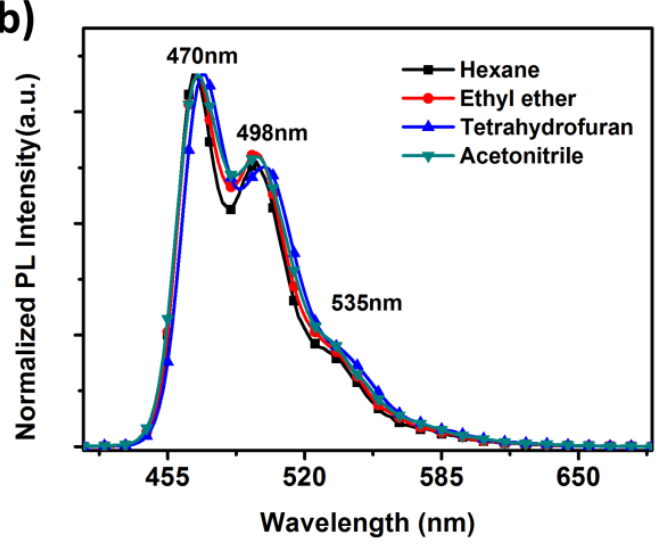

Figure S5. (a) UV-vis absorption (abs) spectra and (b) fluorescence spectra of 2SF-3PE solutions with increasing solvent polarity at concentration of $\sim 10^{-5} \mathrm{M}$. 


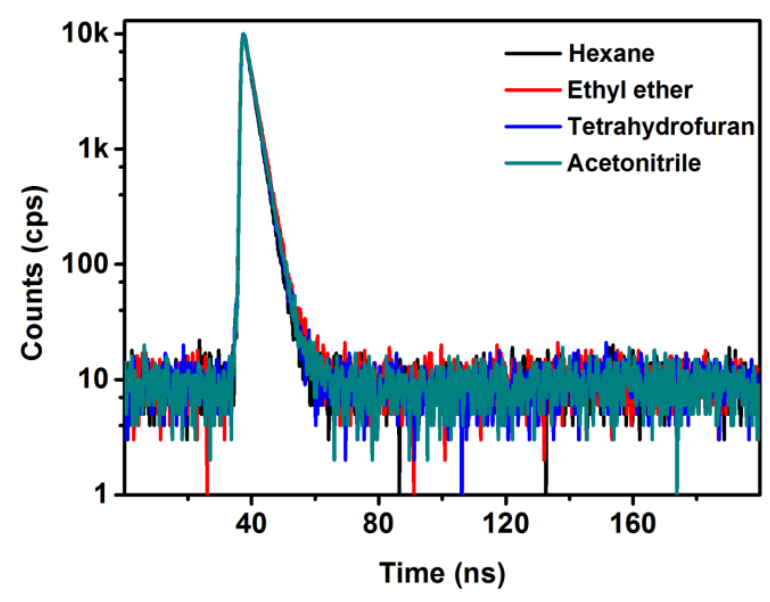

Figure S6. The lifetimes of $2 \mathrm{SF}-3 \mathrm{PE}$ solutions with increasing solvent polarity at concentration of $\sim 10^{-5}$ M. For 2SF-3PE solution in hexane $(\tau=2.54 \mathrm{~ns})$, ethyl ether $(\tau=2.82 \mathrm{~ns})$, THF $(\tau=2.64 \mathrm{~ns})$, acetonitrile $(\tau=2.69 \mathrm{~ns})$.

(a)

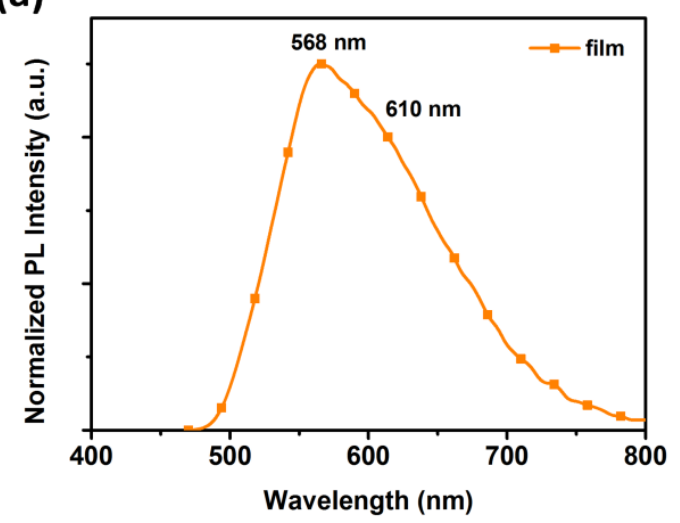

(b)

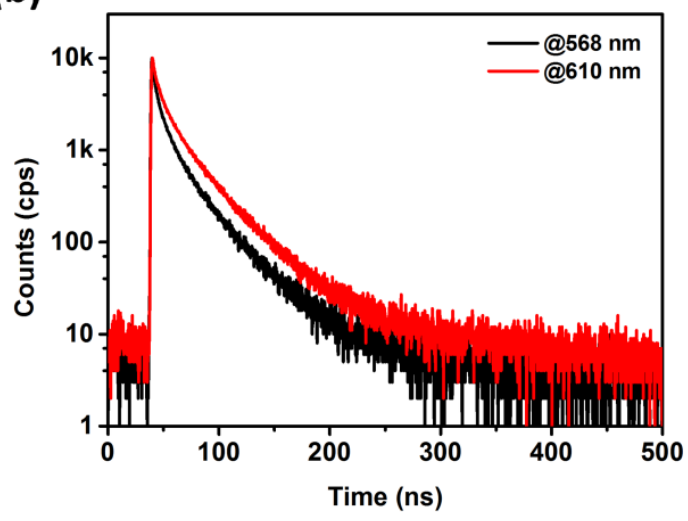

Figure S7. (a) Fluorescence spectrum and (b) lifetime of 2SF-3PE film. The thickness of neat film is about $40 \mathrm{~nm}$. The PL spectrum was excitated at $435 \mathrm{~nm}$, and lifetime is $\tau_{1}=2.64 \mathrm{~ns}(16.25 \%), \tau_{2}=$ $11.84 \mathrm{~ns}(47.11 \%), \tau_{3}=36.33 \mathrm{~ns}(36.64 \%)$ when was recorded at $568 \mathrm{~nm}, \tau_{1}=4.54 \mathrm{~ns}(18.29 \%), \tau_{2}=$ $20.11 \mathrm{~ns}(55.38 \%), \tau_{3}=47.61 \mathrm{~ns}(26.33 \%)$ when was recorded at $610 \mathrm{~nm}$. 
(a)

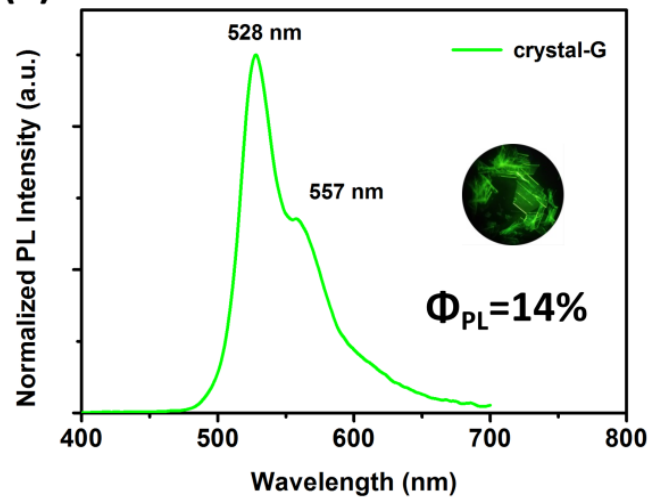

(b)

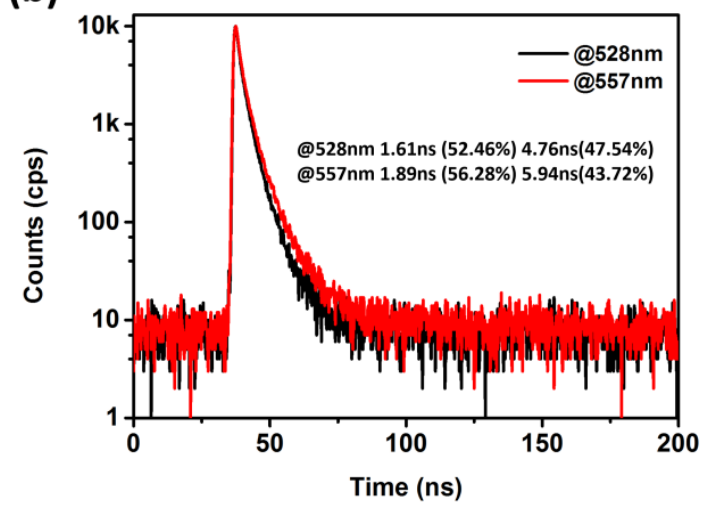

Figure S8. (a) Fluorescence spectra and (b) lifetimes of 2SF-3PE crystal-G.

\section{Photophysical property of PE a-phase crystal}

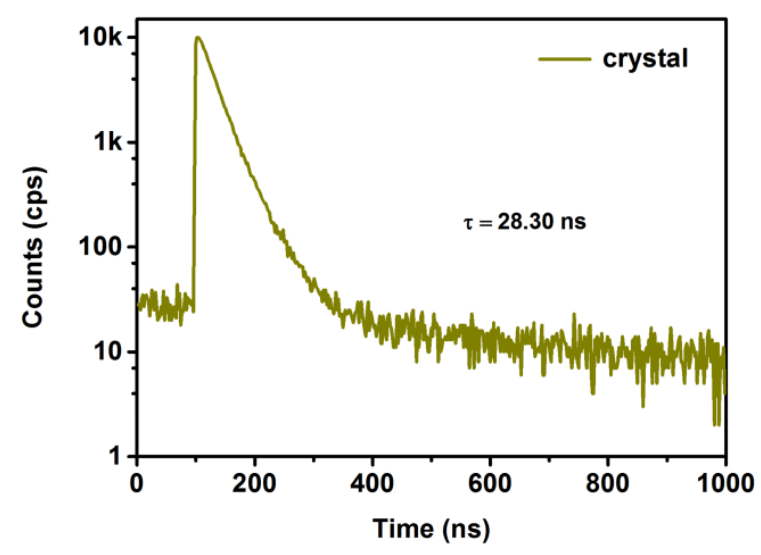

Figure S9. Lifetime of $\alpha$-phase PE crystal. 


\section{Crystal structure}

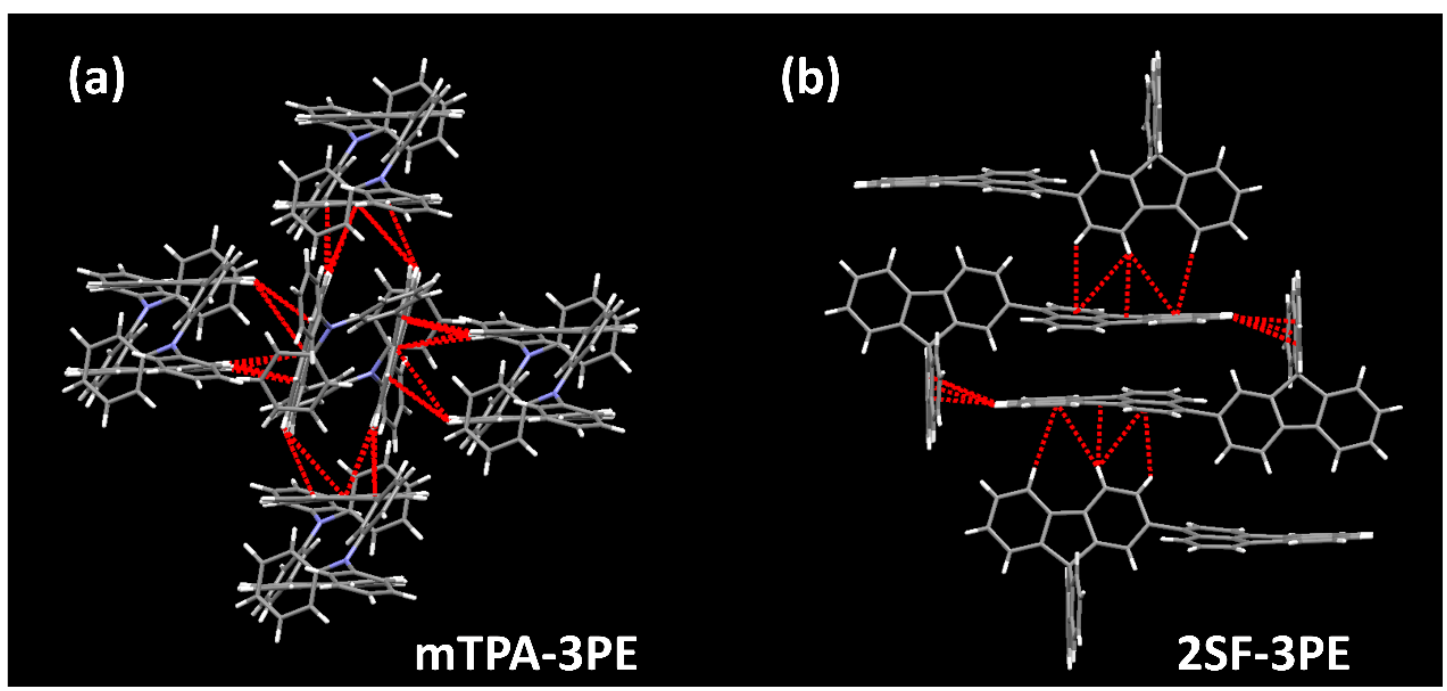

Figure S10. C-H $\cdots \pi$ interactions in (a) mTPA-3PE crystal (the distances is $2.847 \AA-3.958 \AA$ ) and (b) 2SF-3PE crystal (the distances is $2.903 \AA-3.756 \AA$ ).

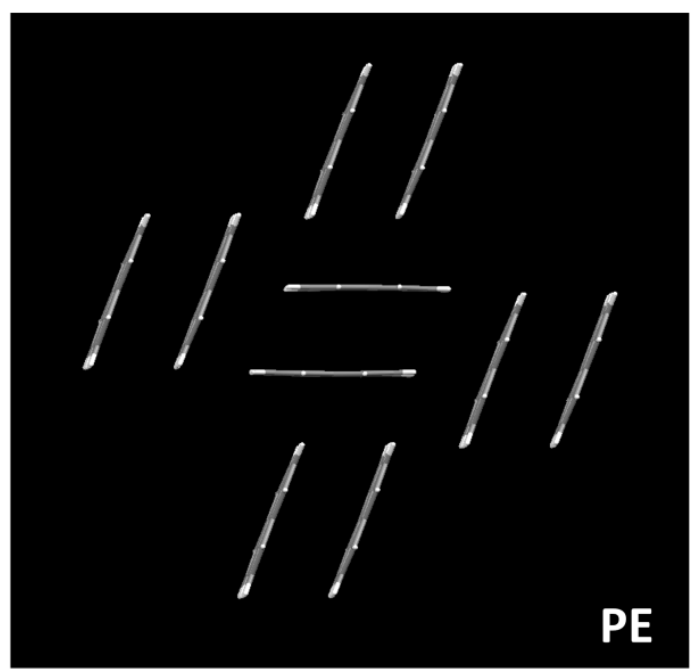

Figure S11. Stacking structure of $\alpha$-phase PE crystal. 


\section{Theoretical calculation}

(a)

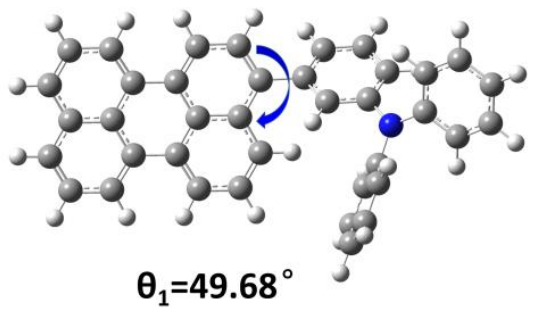

(c)

Transitions

"Hole"

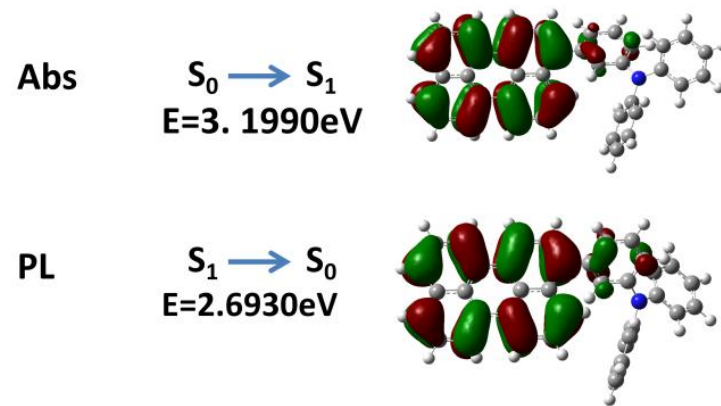

(b)

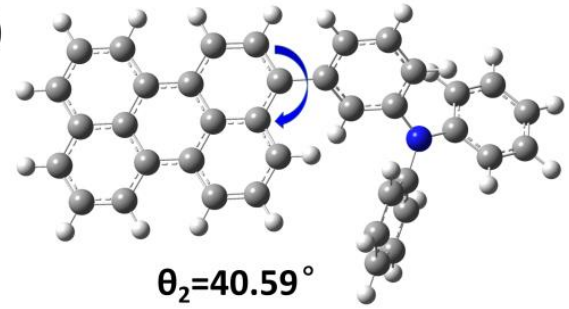

Figure S12. The optimized (a) ground and (b) excited state geometries of mTPA-3PE. (c) NTOs of mTPA-3PE at optimized ground and excited state geometries corresponding to the Abs and PL.

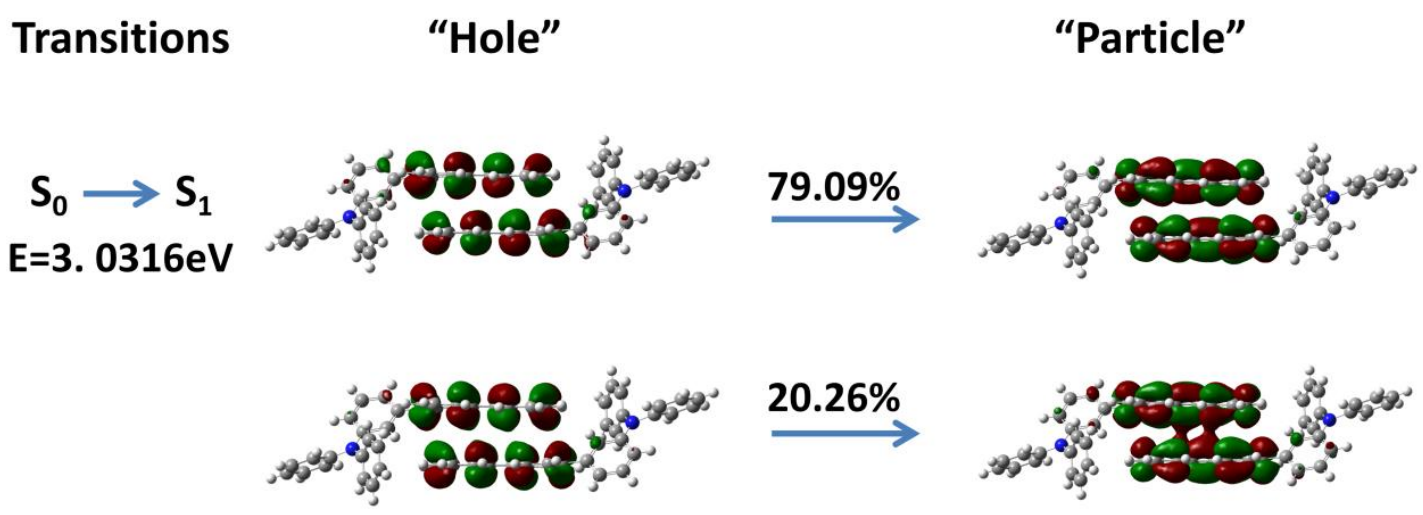

Figure S13. NTOs of mTPA-3PE dimer with "hole" and "particle" distribution at crystal geometry. 


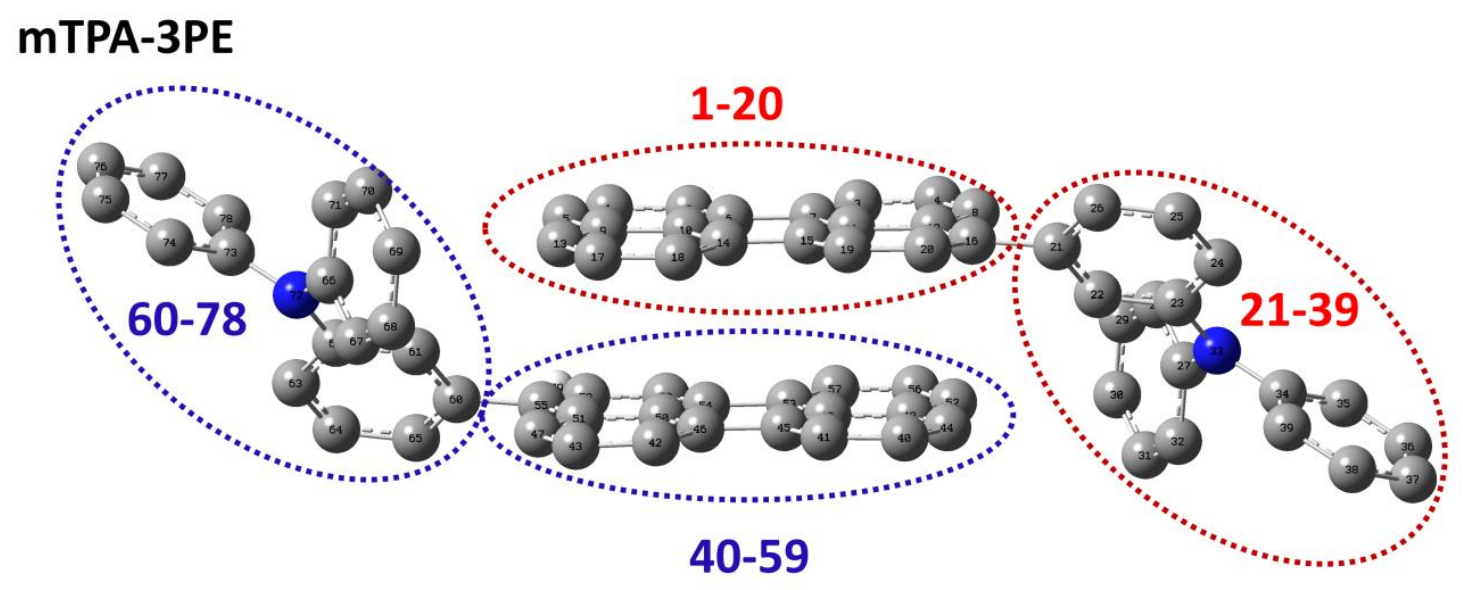

Figure S14. The atoms labels with no $\mathrm{H}$ atom of mTPA-3PE dimer (both labels of the ground and excited state are consistent).

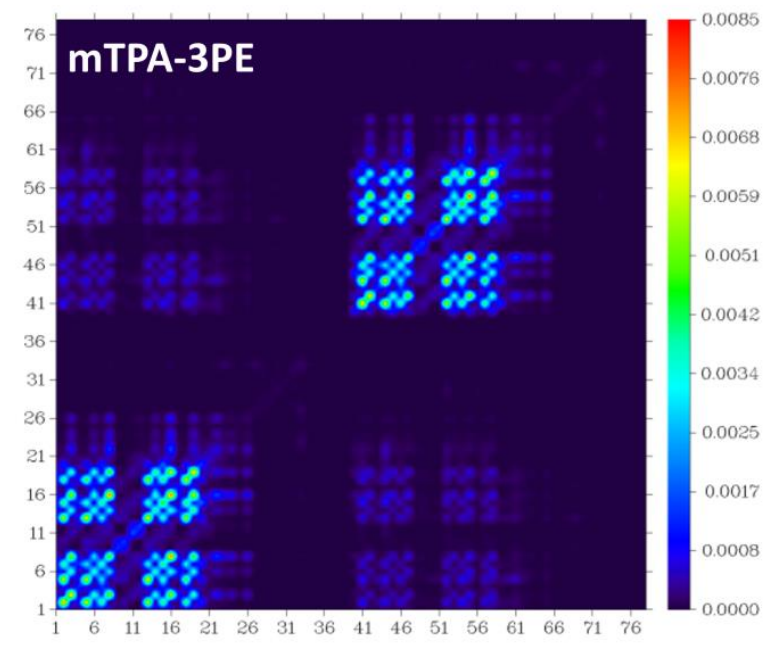

Figure S15. A 2D color-filled map of mTPA-3PE dimer at crystal geometry. 


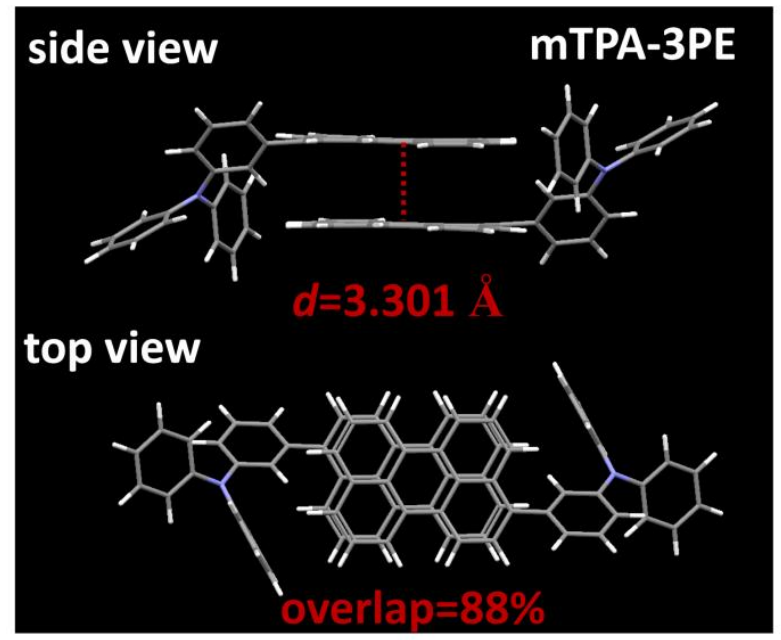

Figure S16. mTPA-3PE dimer geometry of optimized excited state.

(a)

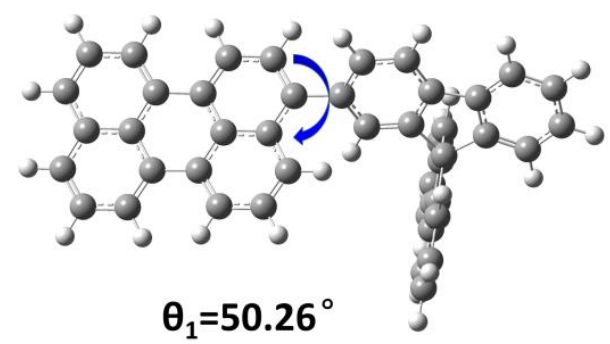

(c)

Transitions

"hole"

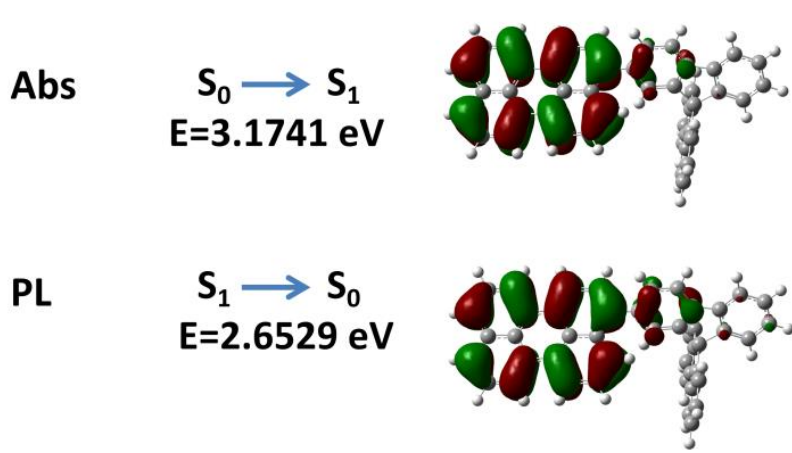

(b)

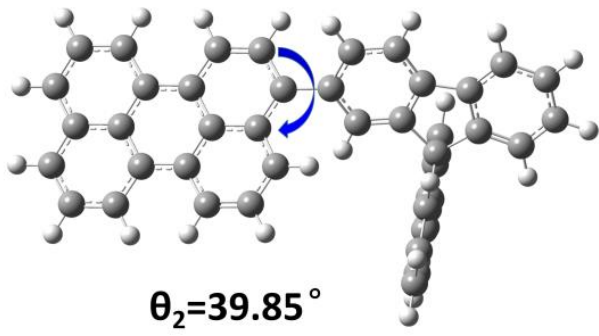

"electron"

$f=0.7919$

$98.75 \%$

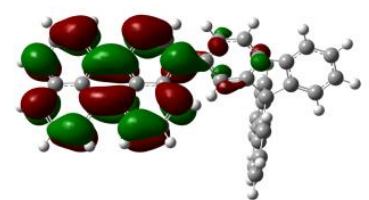

$f=0.8346$

99.65\%

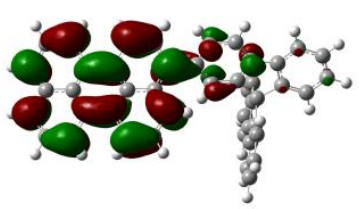

Figure S17. The optimized (a) ground and (b) excited state geometries of 2SF-3PE. (c) NTOs of 2SF3PE at optimized ground and excited state geometries corresponding to the Abs and PL. 


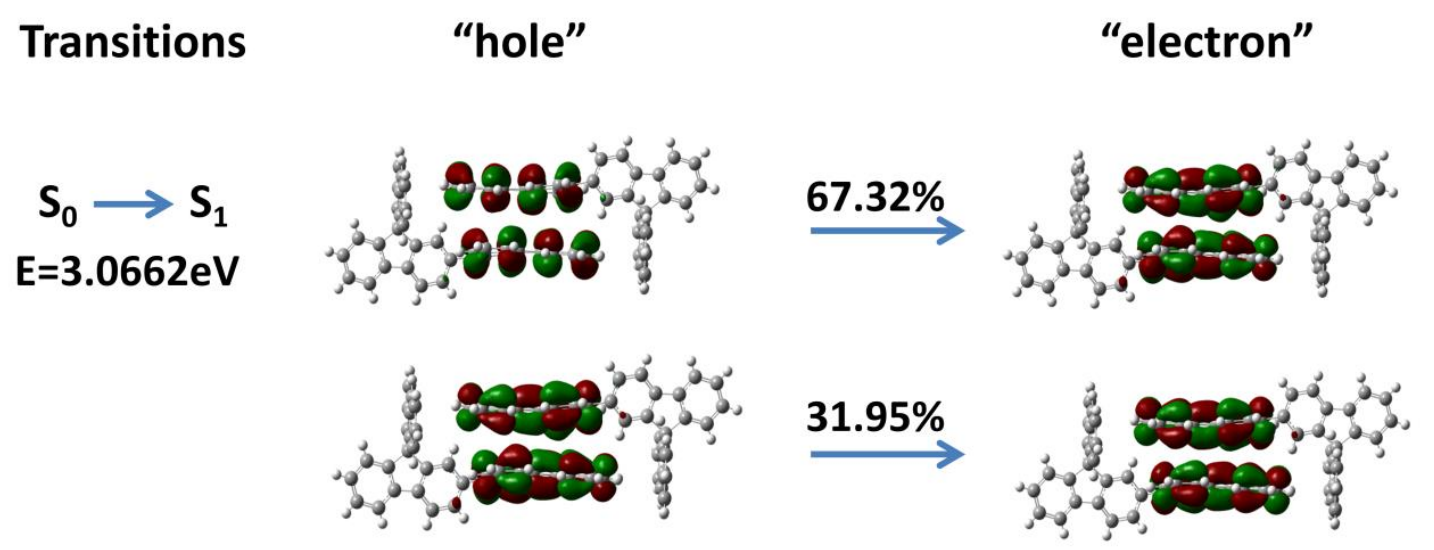

Figure S18. NTOs of 2SF-3PE dimer with "hole" and "particle" distribution at crystal geometry.

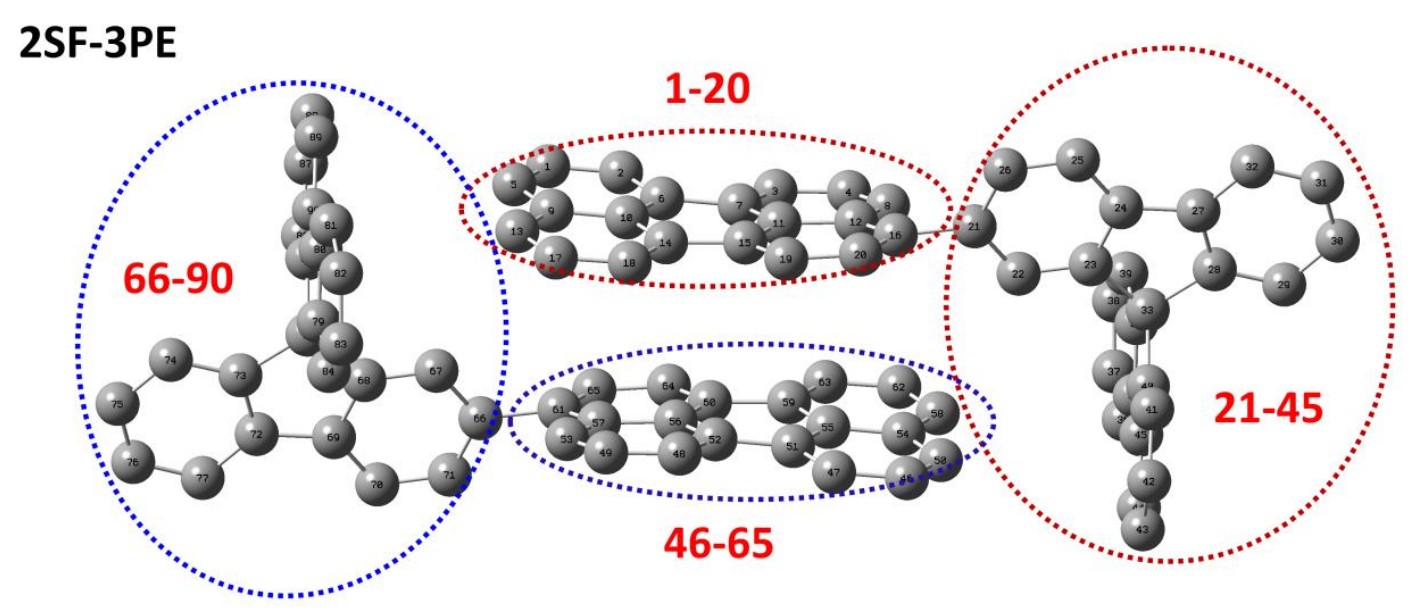

Figure S19. The atoms labels with no $\mathrm{H}$ atom of 2SF-3PE dimer (both labels of the ground and excited state are consistent). 


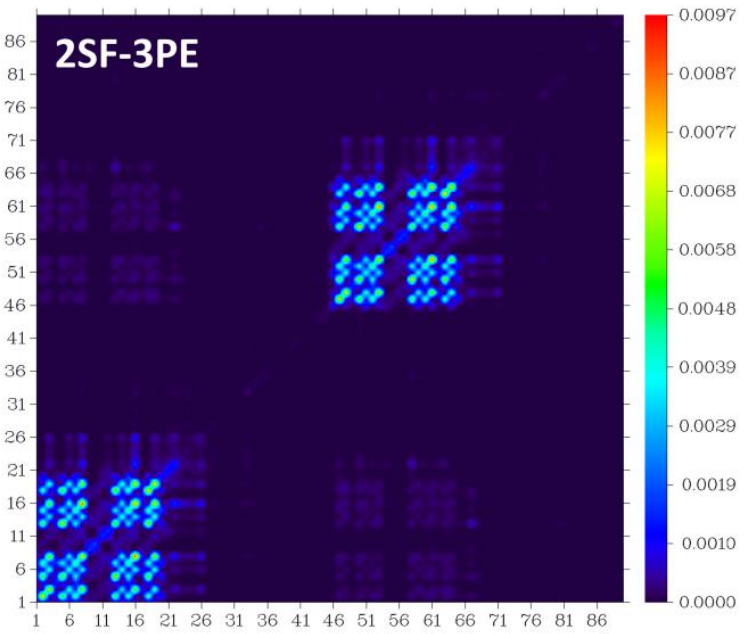

Figure S20. The 2D color-filled map of 2SF-3PE dimer at crystal geometry.

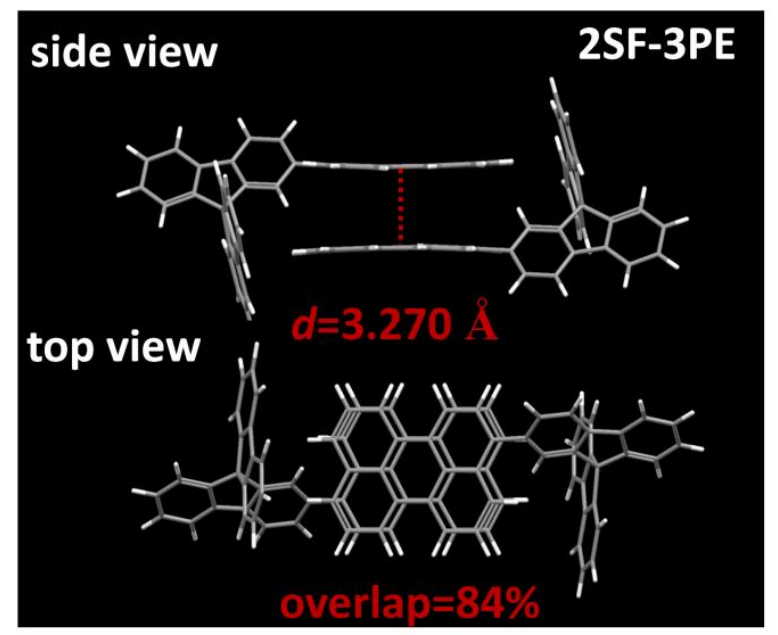

Figure S21. 2SF-3PE dimer geometry of optimized excited state. 


\section{Nanoparticles}

(a)

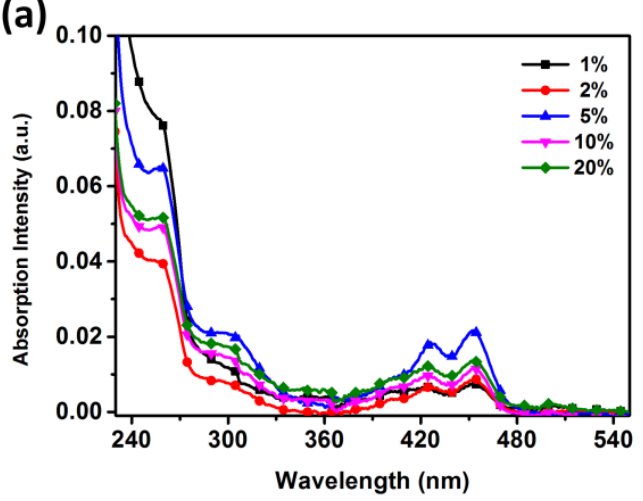

(c)

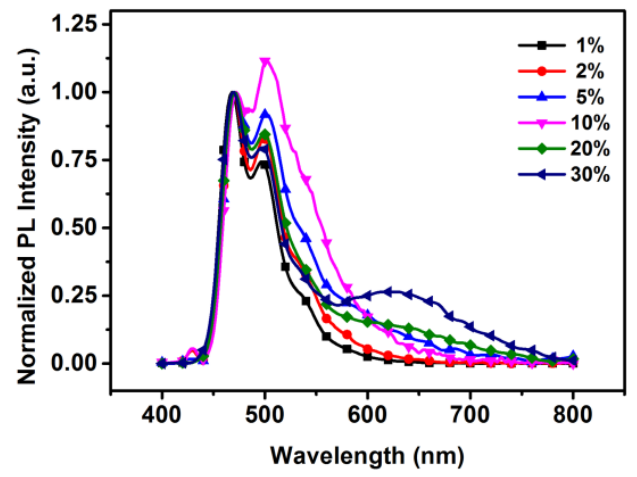

(b)

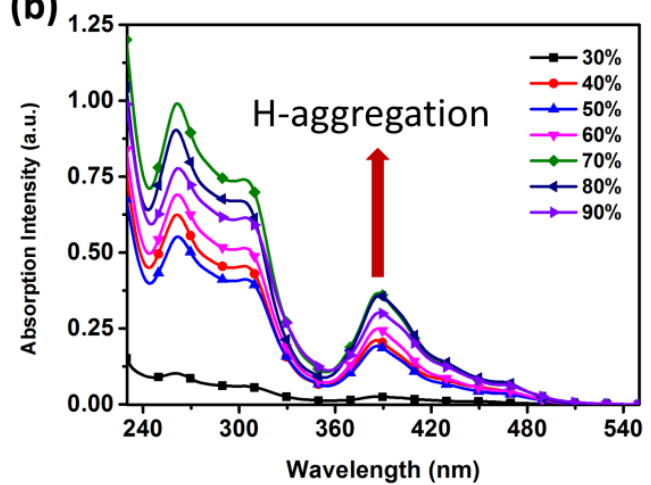

(d)

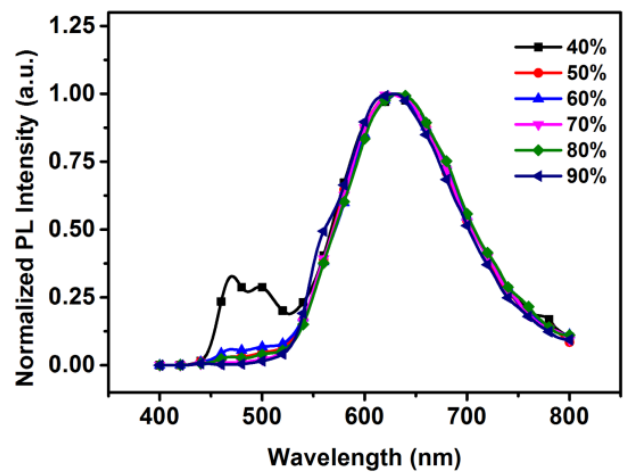

Figure S22. The Abs and PL spectra of mTPA-3PE nanoparticles at different weight ratios (mPSMA:mmTPA3PE).

(a)

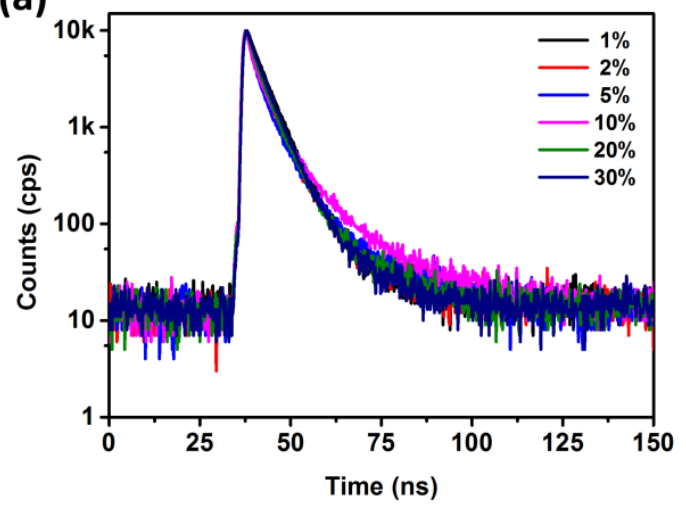

(b)

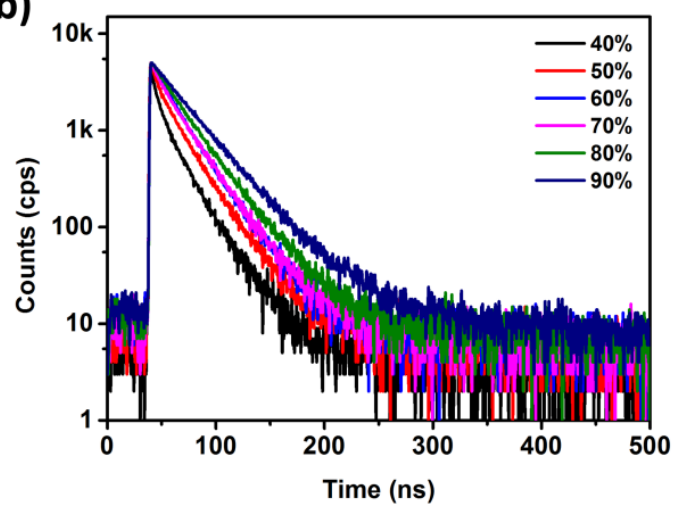

Figure S23. The lifetimes of mTPA-3PE nanoparticles at different weight ratios. 


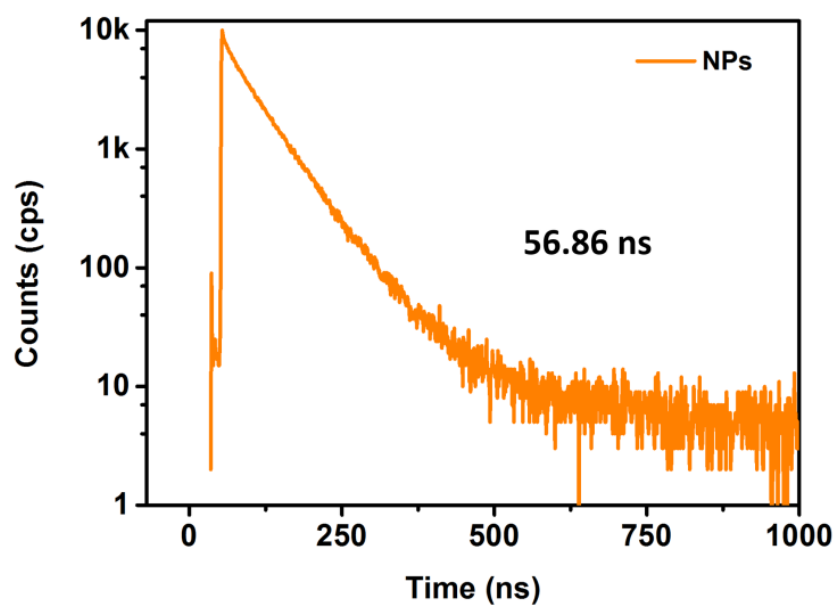

Figure S24. The lifetime of 2SF-3PE nanoparticles at weight ratio of $80 \%$. 
Table S1. Crystal data and structure refinement parameters of mTPA-3PE

\begin{tabular}{|c|c|}
\hline Unit cell parameters & mTPA-3PE \\
\hline crystal color & orange \\
\hline empirical formula & $\mathrm{C}_{38} \mathrm{H}_{25} \mathrm{~N}$ \\
\hline formula weight & 495.59 \\
\hline$T[\mathrm{~K}]$ & $292(2)$ \\
\hline crystal system & monoclinic \\
\hline space group & $\mathrm{P} 2{ }_{1} / \mathrm{c}$ \\
\hline$a[\AA]$ & $20.9204(10)$ \\
\hline$b[\AA]$ & $11.1195(5)$ \\
\hline$c[\AA]$ & $10.9703(6)$ \\
\hline$\alpha\left[^{\circ}\right]$ & 90 \\
\hline$\beta\left[^{\circ}\right]$ & $96.418(3)$ \\
\hline$\gamma\left[^{\circ}\right]$ & 90 \\
\hline$V\left[\AA^{3}\right]$ & $2536.0(2)$ \\
\hline$Z$ & 4 \\
\hline $\mathrm{F}(000)$ & 1046 \\
\hline density $\left[\mathrm{g} / \mathrm{cm}^{3}\right]$ & 1.298 \\
\hline$\mu\left[\mathrm{mm}^{-1}\right]$ & 0.569 \\
\hline reflections collected & 22578 \\
\hline unique reflections & 4367 \\
\hline$R$ (int) & 0.1254 \\
\hline GOF & 0.989 \\
\hline$R_{l}[I>2 \sigma(I)]$ & 0.0793 \\
\hline$\omega R_{2}[I>2 \sigma(I)]$ & 0.1732 \\
\hline$R_{l}$ (all data) & 0.1832 \\
\hline$\omega R 2$ (all data) & 0.2359 \\
\hline CCDC number & 1893817 \\
\hline
\end{tabular}


Table S2. Crystal data and structure refinement parameters of 2SF-3PE

\begin{tabular}{|c|c|}
\hline Unit cell parameters & $2 \mathrm{SF}-3 \mathrm{PE}$ \\
\hline crystal color & yellow \\
\hline empirical formula & $\mathrm{C}_{45} \mathrm{H}_{26}$ \\
\hline formula weight & 566.66 \\
\hline$T[\mathrm{~K}]$ & 293(2) \\
\hline crystal system & monoclinic \\
\hline space group & $\mathrm{P} 2{ }_{1} / \mathrm{c}$ \\
\hline$a[\AA]$ & $9.2921(16)$ \\
\hline$b[\AA]$ & $37.785(7)$ \\
\hline$c[\AA]$ & $8.6845(15)$ \\
\hline$\alpha\left[^{\circ}\right]$ & 90 \\
\hline$\beta\left[^{\circ}\right]$ & $103.090(3)$ \\
\hline$\gamma\left[^{\circ}\right]$ & 90 \\
\hline$V\left[\AA^{3}\right]$ & 2969.9(9) \\
\hline$Z$ & 4 \\
\hline $\mathrm{F}(000)$ & 1184 \\
\hline density $\left[\mathrm{g} / \mathrm{cm}^{3}\right]$ & 1.267 \\
\hline$\mu\left[\mathrm{mm}^{-1}\right]$ & 0.072 \\
\hline reflections collected & 19190 \\
\hline unique reflections & 6216 \\
\hline$R$ (int) & 0.0560 \\
\hline GOF & 0.771 \\
\hline$R_{l}[I>2 \sigma(I)]$ & 0.0618 \\
\hline$\omega R_{2}[I>2 \sigma(I)]$ & 0.1901 \\
\hline$R_{l}$ (all data) & 0.1161 \\
\hline$\omega R 2$ (all data) & 0.2577 \\
\hline CCDC number & 1893816 \\
\hline
\end{tabular}


Table S3. The rate constants.

\begin{tabular}{ccc}
\hline & $\mathrm{k}_{\mathrm{r}}\left(\mathrm{s}^{-1}\right)^{\mathrm{a})}$ & $\mathrm{k}_{\mathrm{nr}}\left(\mathrm{s}^{-1}\right)^{\mathrm{b})}$ \\
\hline PE $\alpha$-phase crystal & $1.27 * 10^{7}$ & $2.26^{*} 10^{7}$ \\
mTPA-3PE crystal & $6.34 * 10^{6}$ & $2.01 * 10^{7}$ \\
2SF-3PE crystal & $1.06 * 10^{7}$ & $3.18^{*} 10^{6}$ \\
\hline
\end{tabular}

${ }^{\text {a) }}$ Radiative decay rate, $\mathrm{k}_{\mathrm{r}}=\eta_{\mathrm{PL}} / \tau$; ${ }^{\mathrm{b})}$ Non-radiative decay rate, $\mathrm{k}_{\mathrm{nr}}=1 / \tau-\mathrm{k}_{\mathrm{r}}$.

Table S4. The lifetimes of mTPA-3PE nanoparticles at different weight ratios.

\begin{tabular}{cccc}
\hline ratio & $\tau_{1}(\mathrm{~ns})$ & $\tau_{2}(\mathrm{~ns})$ & $\tau_{3}(\mathrm{~ns})$ \\
\hline 1 & $4.29(86.86 \%)$ & $9.42(13.14 \%)$ & --- \\
2 & $3.07(63.61 \%)$ & $8.11(36.39 \%)$ & --- \\
5 & $1.52(23.55 \%)$ & $4.88(65.25 \%)$ & $18.0(11.19 \%)$ \\
10 & $1.10(11.62 \%)$ & $4.90(70.33 \%)$ & $17.1(18.06 \%)$ \\
20 & $1.49(10.78 \%)$ & $4.51(80.72 \%)$ & $15.0(8.50 \%)$ \\
30 & $3.99(82.81 \%)$ & $9.02(17.19 \%)$ & --- \\
0640 & 22.61 & --- & --- \\
40 & $5.31(25.95 \%)$ & $22.5(74.05 \%)$ & --- \\
50 & $7.19(19.46 \%)$ & $25.0(83.51 \%)$ & --- \\
60 & 23.7 & --- & --- \\
70 & 24.4 & --- & --- \\
80 & 27.3 & --- & - \\
90 & 32.7 & -- & - \\
\hline
\end{tabular}




\section{S-IV References}

(1) Mitchell, R. H.; Lai, Y. H.; Williams, R. V. N-Bromosuccinimide-Dimethylformamide:A Mild, Selective Nuclear Monobromination Reagent for Reactive Aromatic Compounds. J. Org. Chem. 1979, $44,4733-4735$. 